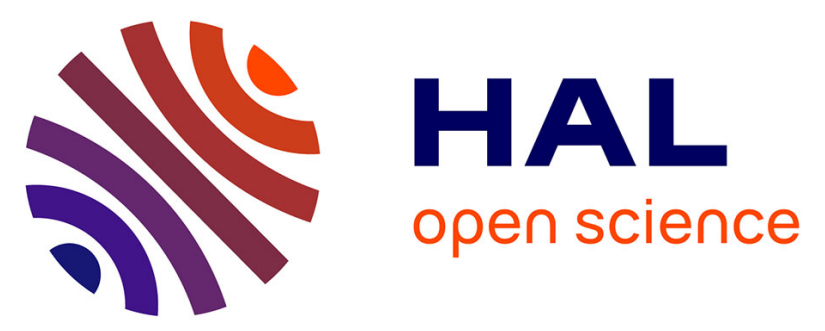

\title{
Neuregulin 1 affects leptin levels, food intake and weight gain in normal-weight, but not obese, $\mathrm{db} / \mathrm{db}$ mice
}

Gaël Ennequin, Nathalie Boisseau, Kévin Caillaud, Vivien Chavanelle, Michel Etienne, Xiaojian Li, Christophe Montaurier, Pascal Sirvent

\section{- To cite this version:}

Gaël Ennequin, Nathalie Boisseau, Kévin Caillaud, Vivien Chavanelle, Michel Etienne, et al.. Neuregulin 1 affects leptin levels, food intake and weight gain in normal-weight, but not obese, $\mathrm{db} / \mathrm{db}$ mice. Diabetes \& Metabolism, 2015, 41 (2), pp.168-172. 10.1016/j.diabet.2014.12.002 . hal-01216265v2

\section{HAL Id: hal-01216265 \\ https://hal.science/hal-01216265v2}

Submitted on 27 Oct 2015

HAL is a multi-disciplinary open access archive for the deposit and dissemination of scientific research documents, whether they are published or not. The documents may come from teaching and research institutions in France or abroad, or from public or private research centers.
L'archive ouverte pluridisciplinaire HAL, est destinée au dépôt et à la diffusion de documents scientifiques de niveau recherche, publiés ou non, émanant des établissements d'enseignement et de recherche français ou étrangers, des laboratoires publics ou privés. 


\title{
Neuregulin 1 affects leptin levels, food intake and weight gain in normal-weight, but not obese, $\mathrm{db} / \mathrm{db}$ mice
}

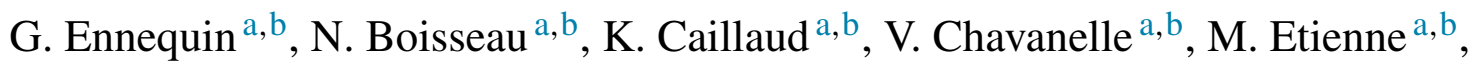 \\ X. Li ${ }^{\mathrm{e}}$, C. Montaurier ${ }^{\mathrm{b}, \mathrm{c}, \mathrm{d}}$, P. Sirvent ${ }^{\mathrm{a}, \mathrm{b}, *}$ \\ ${ }^{a}$ EA 3533, Laboratory of Metabolic Adaptations to Exercise in Physiological and Pathological Conditions, Clermont University, Blaise Pascal University, \\ BP 10448, 63000 Clermont-Ferrand, France \\ ${ }^{\mathrm{b}}$ Clermont University, Auvergne University, Human Nutrition Unit, BP 10448, 63000 Clermont-Ferrand cedex 1, France \\ ${ }^{\mathrm{c}}$ French National Institute for Agricultural Research (INRA), UMR 1019, UNH, CRNH Auvergne, 63000 Clermont-Ferrand, France \\ ${ }^{\mathrm{d}}$ UFR Médecine, University Clermont 1, 63001 Clermont-Ferrand, France \\ e Zensun Sci and Tech Ltd., Shanghai, China
}

Received 27 September 2014; received in revised form 24 November 2014; accepted 2 December 2014

Available online 5 January 2015

\begin{abstract}
Aim. - Studies in vitro have highlighted the potential involvement of neuregulin 1 (NRG1) in the regulation of energy metabolism. This effect has also been suggested in vivo, as intracerebroventricular injection of NRG1 reduces food intakes and weight gain in rodents. Thus, it was hypothesised that NRG1 might affect serum leptin levels in mice.

Methods. - Weight, food intakes, energy expenditure, spontaneous physical activity and serum leptin levels were evaluated in normal-weight C57BL/6JRJ mice following intraperitoneal administration of NRG1 (50 $\mu \mathrm{g} / \mathrm{kg}$, three times/week) or saline for 8 weeks. Based on the results of this first experiment, leptin-resistant obese $\mathrm{db} / \mathrm{db}$ mice were then given NRG1 for 8 weeks.

Results. - Leptin serum concentrations were six times higher in C57BL/6JRJ mice treated with NRG1 than in the animals given saline. NRG1 treatment also reduced weight gain by $10 \%$ and food intakes by $15 \%$ compared with saline treatment, while energy expenditure remained unchanged. In $\mathrm{db} / \mathrm{db}$ mice, serum leptin concentrations, weight gain, food intakes, energy expenditure and spontaneous physical activity were not altered by NRG1 treatment.

Conclusion. - The decrease in food intakes and weight gain associated with NRG1 treatment in C57BL/6JRJ mice may be partly explained by increased leptin levels, whereas db/db mice were not affected by the treatment, suggesting resistance to NRG1 in this pathological state.
\end{abstract}

(C) 2014 Elsevier Masson SAS. All rights reserved.

Keywords: NRG1; Obesity; Energy expenditure; Weight loss

Abbreviations: NRG1, Neuregulin 1 ;ErbB, Erythroblastic leukaemia viral oncogene homologue; RQ, Respiratory quotient; VHL, Vehicle (saline).

* Corresponding author. Laboratoire des Adaptations Métaboliques à l'Exercice en Conditions Physiologiques et Pathologiques (AME2P), Université Blaise-Pascal, Bâtiment Biologie B, 24, avenue des Landais, BP 80026, 63171 Aubière cedex, France. Tel.: +33 4734071 33;

fax: +00 33473405062 .

E-mail address: pascal.sirvent @univ-bpclermont.fr (P. Sirvent).

\section{Introduction}

Neuregulin 1 (NRG1) belongs to the epidermal growth factor family. Its biological activity is mediated by erythroblastic leukaemia viral oncogene homologue (ErbB) receptors. NRG1 plays a fundamental role in both developing and mature heart tissue, and NRG1 treatment has positive effects in cardiovascular diseases [1]. Altered NRG1/ErbB signalling has been demonstrated during the development and progression of many tumours [2]. Complex crosstalk between ErbB2 receptors and leptin appears to take place in cancer [3], and ErbB2 induces leptin transcriptional upregulation in human breast epithelial cells [4]. 
As leptin plays a major role in energy balance regulation, and given the link between leptin and NRG1/ErbB signalling in cancer, it was hypothesized that NRG1 treatment might alter leptin levels.

Therefore, the effect of chronic (8-week) intraperitoneal (i.p.) NRG1 treatment on leptin, weight status, fat mass, food intakes, physical activity and energy expenditure was assessed in normalweight mice and, based on the results of this first experiment, in leptin-resistant $\mathrm{db} / \mathrm{db}$ mice also.

\section{Methods}

\subsection{Animals}

A total of $16 \mathrm{C} 57 \mathrm{BL} / 6 \mathrm{JRJ}$ and $16 \mathrm{BKS}(\mathrm{D})-\mathrm{Lepr}^{d b} / J O r l R j$ mice (10 weeks old), provided by CERJ Janvier (Le GenestSaint-Isle, France), were kept in temperature-controlled $\left(20-22{ }^{\circ} \mathrm{C}\right)$ cages (single-housed) with free access to water and food (A04 diet; Scientific Animal Food and Engineering, France). All animal husbandry and experimental procedures were in accordance with the current legislation on animal experimentation, and were approved by the local ethics committee (CEMEA Auvergne, CE 97-12).

\subsection{NRG1 treatment}

Recombinant NRG1 (beta-2a; Zensun Sci and Tech, Shanghai, China) [5] at $50 \mu \mathrm{g} / \mathrm{kg}$ body weight or an equivalent volume of $0.9 \% \mathrm{NaCl}$ (sodium chloride) was administered by i.p. injection three times a week for 8 weeks $(n=8$ for each group). Mice were euthanised 3 days after the end of treatment.

\subsection{Food intakes, body mass and body composition}

Body weight and food intakes were recorded every week during the treatment period. One week before sacrifice, body composition was evaluated by quantitative nuclear magnetic resonance imaging (EchoMRI; Echo Medical Systems, Houston, TX, USA).

\subsection{Daily energy expenditure and physical activity}

$\mathrm{VO}_{2}, \mathrm{VCO}_{2}$ and physical activity were measured in mice using a PhenoMaster/LabMaster home cage system (TSE Systems, Bad Homburg, Germany). Energy expenditure was calculated using the Weir equation [6] from measurements of gas exchanges computed for each cage from data sampled every 5 min. Respiratory quotient (RQ) was determined from $\mathrm{VCO}_{2} / \mathrm{VO}_{2}$. Spontaneous activity was measured using threedimensional meshes of light beams. For adaptation, mice were placed in individual calorimetric cages $\left(22^{\circ} \mathrm{C}\right)$ for $24 \mathrm{~h}$ prior to data collection. Daily energy expenditure and physical activity were computed for a $24-\mathrm{h}$ period.

\subsection{Leptin measurement}

Serum leptin was evaluated with an ELISA kit (Abcam, Cambridge, MA, USA), and samples were read at $450 \mathrm{~nm}$ using a PowerWave spectrophotometer (US BioTek, North Shoreline, WA, USA).

\subsection{Statistical analysis}

SPSS Advanced Statistics software was used for the statistical analysis (IBM, Armonk, NY, USA). Data are presented as the mean \pm SEM. One-way analysis of variance (ANOVA) with repeated measures was performed to assess weight and food intake changes following NRG1 or saline treatment. Unpaired Student's $t$ test was used where appropriate. Statistical significance was set at $P<0.05$.

\section{Results}

\subsection{NRG1 increases serum leptin and decreases weight gain, food intakes and spontaneous physical activity in C57BL/6JRJ mice}

On evaluating NRG1 effects in C57BL/6JRJ mice (Fig. 1), serum leptin was strongly increased compared with the saline vehicle (VHL)-treated animals $\left(183.4 \pm 46.6 \mathrm{pg} \cdot \mathrm{mL}^{-1} v s\right.$. $29.5 \pm 5.1$ pg. $\mathrm{mL}^{-1}$, respectively; $P<0.05$; Fig. $\left.1 \mathrm{~A}\right)$. The VHL group also gained $9.6 \%$ in body mass (from $25.1 \pm 0.95 \mathrm{~g}$ to $27.6 \pm 0.85 \mathrm{~g}$ ) whereas, in NRG1-treated mice, weight remained stable (from $26.6 \pm 0.52 \mathrm{~g}$ to $26.1 \pm 0.43 \mathrm{~g}$ ) with treatment (Fig. 1B). Similarly, food intakes increased by $15.3 \%$ in the VHL group (from $27.1 \pm 0.59$ g.week $^{-1}$ to $31.5 \pm 1.5$ g.week $^{-1}$; $P<0.05$; Fig. 1C), but did not change in NRG1-treated mice

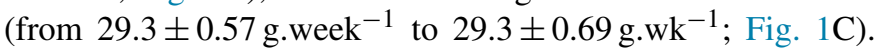
At the end of the treatment period, body fat percentages were lower in the NRG1 than in the VHL group $(12.5 \pm 0.67 \%$ vs. $16.3 \pm 0.91 \%$, respectively; $P<0.05$; Fig. 1D). Daily energy expenditure (Fig. 1E) and RQ (not shown) did not differ between the groups. Spontaneous activity over $24 \mathrm{~h}$ and at night was lower in the NRG1 than in the VHL group $(288.2 \pm 31.5 \mathrm{~m} v \mathrm{~s}$. $502.6 \pm 102.3 \mathrm{~m}$ and $227.7 \pm 24.9$ vs. $373.6 \pm 56.1 \mathrm{~m}$, respectively; $P<0.05)$, whereas diurnal activity was similar in both groups (Fig. 1F).

\subsection{NRG1 has no effect on serum leptin, weight gain, food intakes or spontaneous physical activity in $\mathrm{db} / \mathrm{db}$ mice}

As NRG1 treatment increased serum leptin levels in C57BL/6JRJ mice, it was postulated that NRG1 effects might be blunted in leptin-resistant $\mathrm{db} / \mathrm{db}$ mice. Serum leptin concentrations were comparable in both NRG1- and VHL-treated db/db mice (Fig. 2A). Similarly, weight (Fig. 2B) and food intakes (Fig. 2C) remained stable in both groups of $\mathrm{db} / \mathrm{db}$ mice, and the percentage of body fat was also comparable in both groups at the end of treatment (Fig. 2D). Energy expenditure (Fig. 2E), 
A

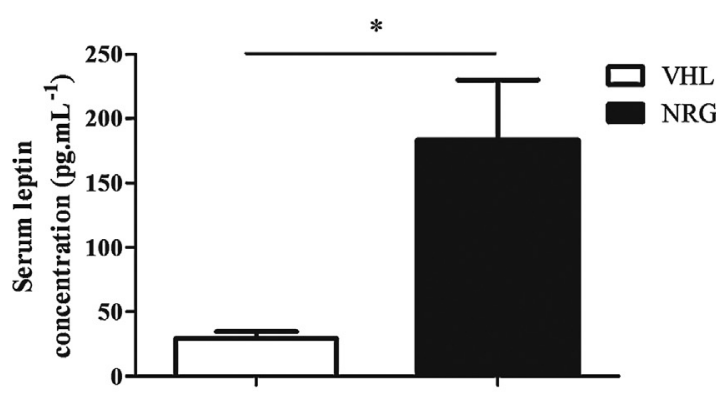

C

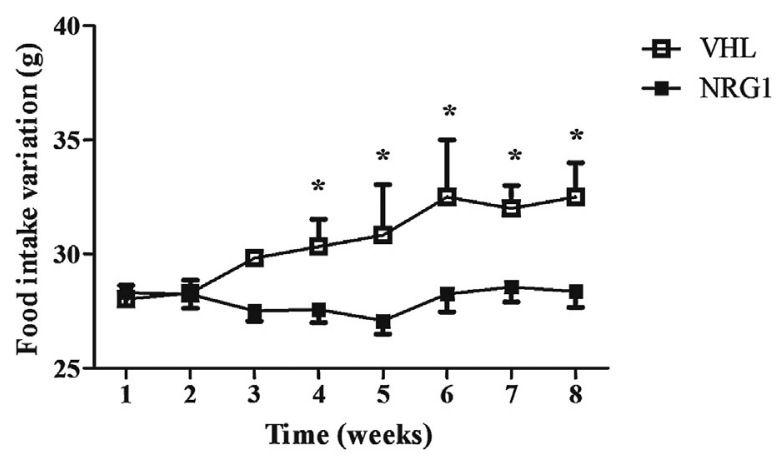

B

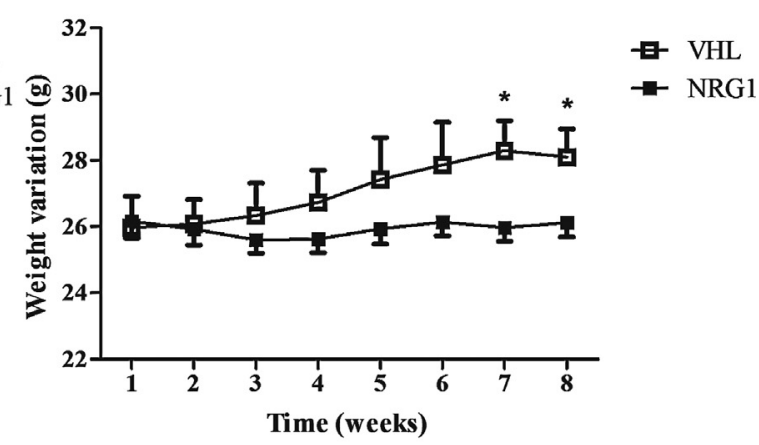

D
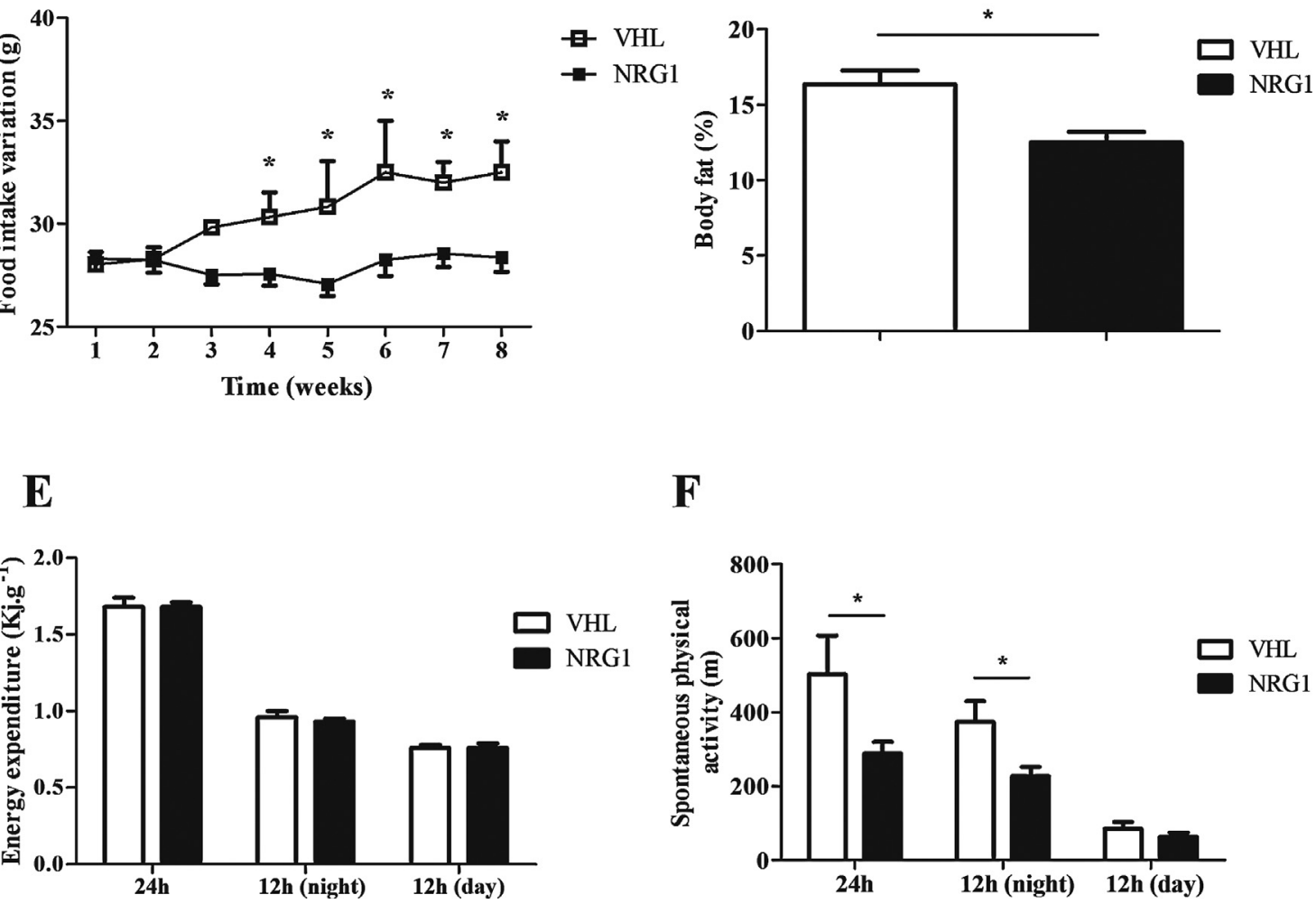

$\mathbf{F}$

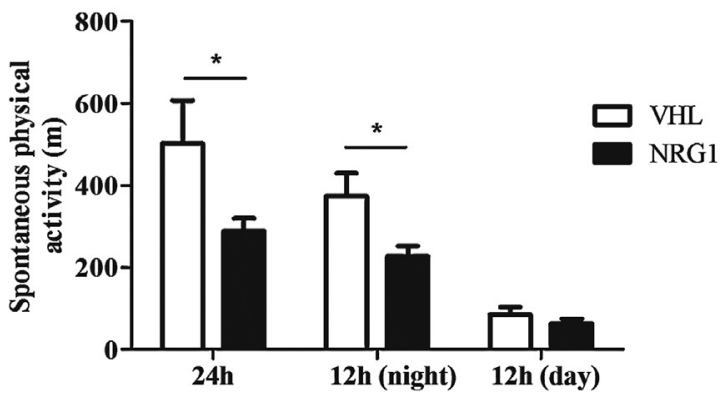

Fig. 1. Effects of 8-week neuregulin 1 (NRG1) and saline (VHL) intraperitoneal treatment in normal-weight C57BL/6JRJ mice. (A) Serum leptin concentrations at the end of NRG1 $\left(50 \mu \mathrm{g} . \mathrm{kg}^{-1}\right)$ and saline treatment; variations (as percentages) in (B) body weight and (C) food intake during NRG1 and saline treatment; and (D) body fat, (E) energy expenditure and (F) spontaneous physical activity at the end of treatment. Values are means \pm SEM $\left(n=8 /\right.$ condition). ${ }^{*} P<0.05 v s$. VHL-treated mice.

RQ (not shown) and spontaneous physical activity (Fig. 2F) did not significantly differ between groups.

\section{Discussion}

Our results show that, in C57BL/6JRJ mice, NRG1 treatment increases serum leptin concentrations, prevents weight gain and lowers food intakes compared with saline-treated controls. In contrast, NRG1 had no significant effects in $\mathrm{db} / \mathrm{db}$ mice.

The strong leptin increase in C57BL/JJRJ mice after 8 weeks of NRG1 treatment might explain the decreases in food intakes, weight gain and body fat percentages, as shown previously with leptin treatment [7]. The cause of the leptin increase, however, is unknown. Leptin production is indirectly under insulin control via the PI3 K/AKT signalling pathway [8], and NRG1 stimulates this pathway in muscle cells [9]. ErbB2 activation upregulates leptin in human breast epithelial cells [4]. However, it is not known whether NRG1 administration can affect white adipose tissue, the main leptin producer [8]. The fact that ErbB receptors are expressed in human preadipocytes [10] allows the assumption that adipose tissue may be involved in the NRG1-mediated increase in leptin.

Alternatively, leptin levels might be regulated centrally, as the brain has been shown to express leptin and to release it into 
A

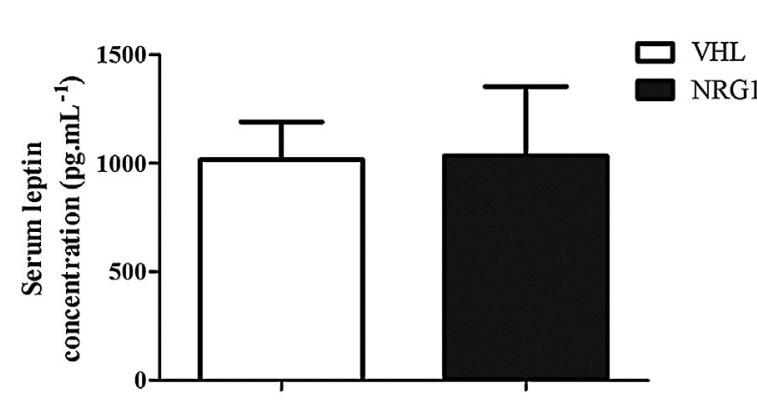

C

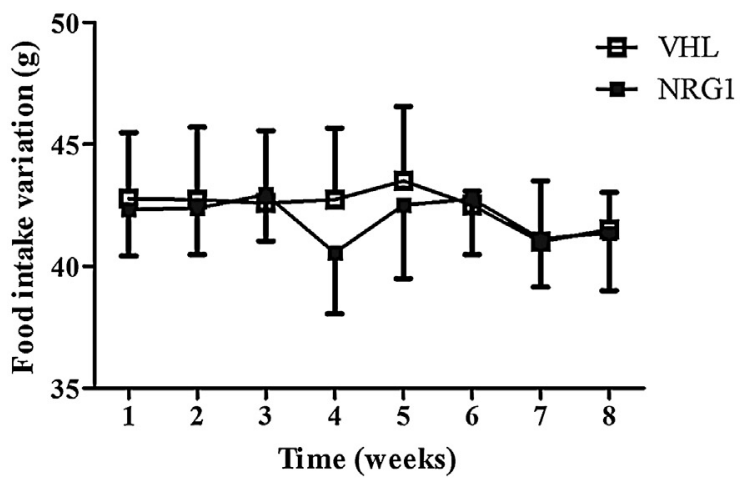

E

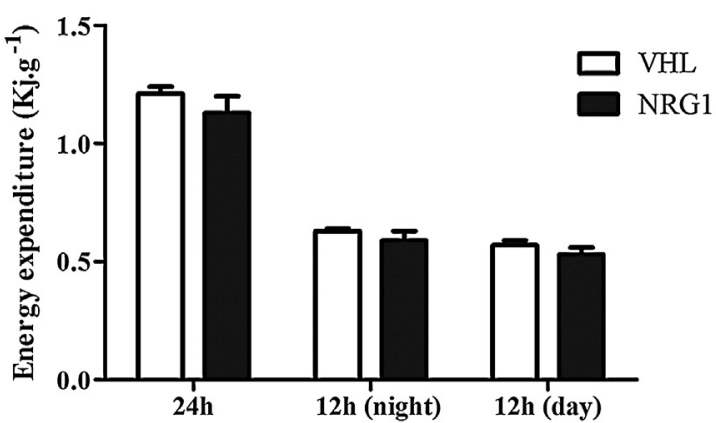

B

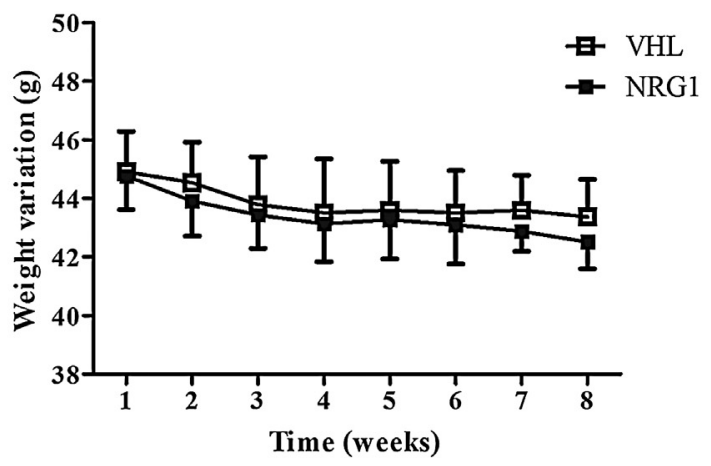

D

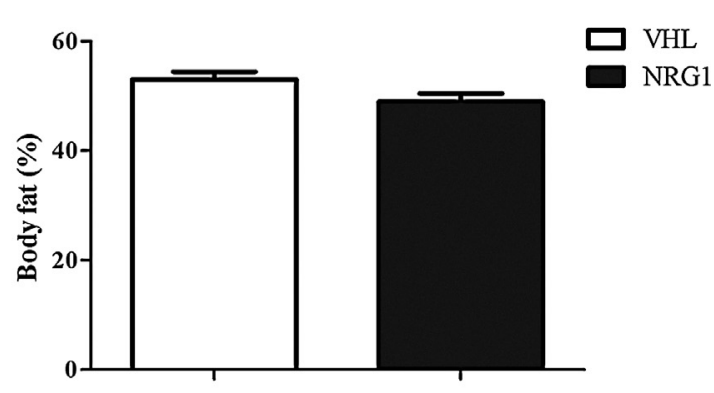

F

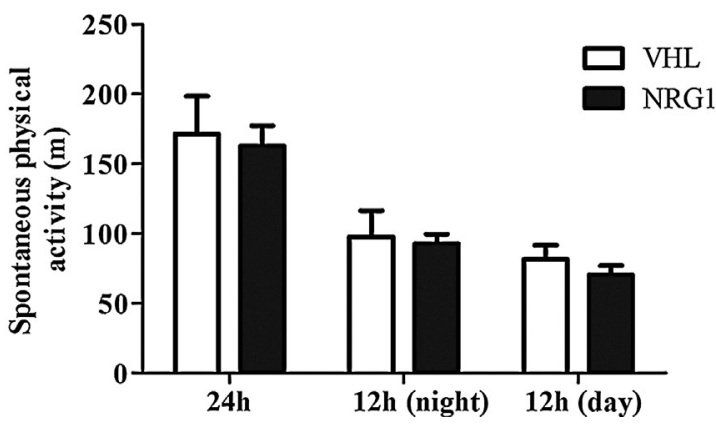

Fig. 2. Effects of 8-week intraperitoneal treatment with neuregulin 1 (NRG1) and saline (VHL) in obese db/db mice. (A) Serum leptin concentrations at the end of NRG1 $\left(50 \mu \mathrm{g} \cdot \mathrm{kg}^{-1}\right)$ and saline treatment; variations (as percentages) in (B) body weight and (C) food intake between weeks 1 and 8 ; and (D) body fat, (E) energy expenditure and (F) spontaneous physical activity at the end of treatment. Values are means \pm SEM ( $n=8 /$ condition).

the bloodstream [11]. Indeed, intracerebroventricular injection of NRG1 in hamsters had effects on food intakes and weight gain similar to those reported in our study [12], suggesting that the brain may be participating in the NRG1-mediated increase in circulating leptin, although it cannot be excluded that NRG1 effects may also be independent of leptin. Also, there is evidence to suggest that NRG1 could also have leptin-independent effects. Spontaneous physical activity was markedly decreased in normal-weight mice, as previously reported [12], while total energy expenditure was not affected by NRG1 treatment.

These results suggest that the resting metabolic rate, which represents a major component of total energy expenditure (about $86 \%$ in mice [13]), could compensate for the decreased energy expenditure from physical activity, resulting in unchanged total daily energy expenditure. Nevertheless, leptin is known to increase both spontaneous physical activity and energy expenditure [14]. Therefore, our present results suggest a complex action of NRG1 whereby food intakes and weight gain are both decreased possibly through an increase in leptin, while physical activity and energy expenditure are limited through unknown pathways. However, the possibility of a side-effect induced by NRG1 treatment that might promote a decrease in mouse locomotion cannot be ruled out, although human studies using comparable dose ranges have shown no such significant side-effect induced by chronic NRG1 treatment $[15,16]$. More studies are now needed to elucidate the origin of the 
NRG1-induced increase in circulating leptin and the contribution of increased circulating leptin to altered food intakes and weight gain.

Unexpectedly, none of the effects observed in C57BL/6JRJ mice following NRG1 treatment were seen in the leptin-resistant obese $\mathrm{db} / \mathrm{db}$ mice, and serum leptin concentrations did not increase. This result suggests that the NRG1/ErbB signalling pathway might be impaired in these mice. As NRG1 activates the PI3K/Akt pathway [9], insulin resistance in $\mathrm{db} / \mathrm{db}$ mice could have inhibited leptin production, which is triggered by these kinases [10]. Moreover, palmitate impairs NRG1 signalling in rat cardiac myocytes [17]. This suggests that the dyslipidaemia commonly seen in metabolic diseases, and particularly in $\mathrm{db} / \mathrm{db}$ mice, might perturb NRG1 signalling. Such an NRG1-resistant state could, in turn, result in silenced leptin upregulation.

In conclusion, our present study has demonstrated that chronic NRG1 administration increases serum leptin concentration in normal-weight mice, and this increase might partly explain the reduction in food intakes, body weight gain and body fat percentage in these mice. On the other hand, NGR1 treatment appeared to have no such effects in obese $\mathrm{db} / \mathrm{db}$ mice, suggesting 'NRG1 resistance' in this pathological state.

\section{Disclosure of interest}

Xinyan Li is employed by Zensun Sci and Tech Ltd.

\section{Acknowledgements}

We thank Zensun Sci and Tech Ltd. for their advice and gift of rhNRG1.

\section{References}

[1] Odiete O, Hill MF, Sawyer DB. Neuregulin in cardiovascular development and disease. Circ Res 2012;111:1376-85.

[2] Montero JC, Rodriguez-Barrueco R, Ocana A, Diaz-Rodriguez E, EsparisOgando A, Pandiella A. Neuregulins and cancer. Clin Cancer Res 2008:14:3237-41

[3] Fiorio E, Mercanti A, Terrasi M, Micciolo R, Remo A, Auriemma A, et al. Leptin/HER2 crosstalk in breast cancer: in vitro study and preliminary in vivo analysis. BMC Cancer 2008;8:305.
[4] Cha Y, Kang Y, Moon A. HER2 induces expression of leptin in human breast epithelial cells. BMB Rep 2012;45:719-23.

[5] Liu X, Gu X, Li Z, Li X, Li H, Chang J, et al. Neuregulin1/erbB-activation improves cardiac function and survival in models of ischemic, dilated, and viral cardiomyopathy. J Am Coll Cardiol 2006;48: 1438-47.

[6] Weir JB. New methods for calculating metabolic rate with special reference to protein metabolism. Nutrition 1990;6:213-21 [1949].

[7] Halaas JL, Gajiwala KS, Maffei M, Cohen SL, Chait BT, Rabinowitz D, et al. Weight-reducing effects of the plasma protein encoded by the obese gene. Science 1995;269:543-6.

[8] Lee MJ, Fried SK. Integration of hormonal and nutrient signals that regulate leptin synthesis and secretion. Am J Physiol Endocrinol Metab 2009;296:E1230-8

[9] Suarez E, Bach D, Cadefau J, Palacin M, Zorzano A, Guma A. A novel role of neuregulin in skeletal muscle. Neuregulin stimulates glucose uptake, glucose transporter translocation, and transporter expression in muscle cells. J Biol Chem 2001;276:18257-64.

[10] Rogers C, Moukdar F, McGee MA, Davis B, Buehrer BM, Daniel KW, et al. EGF receptor (ERBB1) abundance in adipose tissue is reduced in insulin-resistant and type 2 diabetic women. J Clin Endocrinol Metab 2012;97:E329-40.

[11] Wiesner G, Vaz M, Collier G, Seals D, Kaye D, Jennings G, et al. Leptin is released from the human brain: influence of adiposity and gender. J Clin Endocrinol Metab 1999;84:2270-4.

[12] Snodgrass-Belt P, Gilbert JL, Davis FC. Central administration of transforming growth factor-alpha and neuregulin-1 suppress active behaviors and cause weight loss in hamsters. Brain Res 2005;1038: $171-82$.

[13] Van Klinken JB, van den Berg SA, Havekes LM, Willems Van Dijk K. Estimation of activity related energy expenditure and resting metabolic rate in freely moving mice from indirect calorimetry data. PLOS ONE 2012; 7:e36162.

[14] Choi YH, Li C, Hartzell DL, Little DE, Della-Fera MA, Baile CA. ICV leptin effects on spontaneous physical activity and feeding behavior in rats. Behav Brain Res 2008;188:100-8.

[15] Gao R, Zhang J, Cheng L, Wu X, Dong W, Yang X, et al. Phase II randomized, double-blind, multicenter, based on standard therapy, placebo-controlled study of the efficacy and safety of recombinant human neuregulin-1 in patients with chronic heart failure. J Am Coll Cardiol 2010;55:1907-14.

[16] Jabbour A, Hayward CS, Keogh AM, Kotlyar E, McCrohon JA, England JF, et al. Parenteral administration of recombinant human neuregulin1 to patients with stable chronic heart failure produces favourable acute and chronic haemodynamic responses. Eur J Heart Fail 2011;13: 83-92.

[17] Miller TA, Icli B, Cote GM, Lebrasseur NK, Borkan SC, Pimentel DR, et al. Palmitate alters neuregulin signaling and biology in cardiac myocytes. Biochem Biophys Res Commun 2009:379:32-7. 